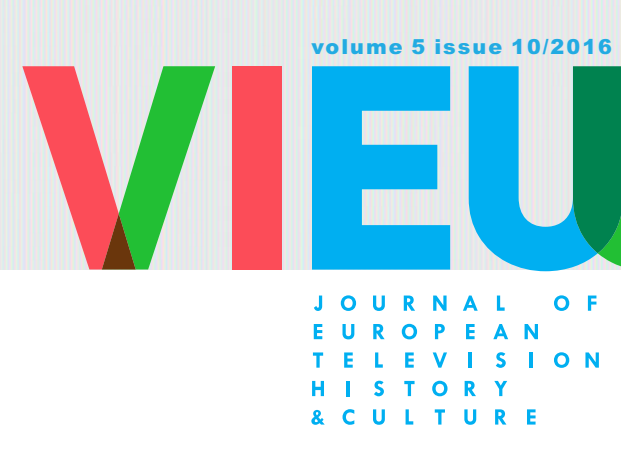

\title{
CROSSROADS: LIFE CHANGING STORIES FROM THE SECOND WORLD WAR
}

\section{A (TRANSMEDIA) STORYTELLINGAPPROACH TOWORLD WAR II HERITAGE}

\author{
Licia Calvi \\ NHTV University of Applied Sciences \\ Academy for Digital Entertainment/Academy for Leisure \\ Hopmansstraat 1, 4800 DX \\ Breda \\ The Netherlands \\ calvi..@nhtv.nl \\ Moniek Hover \\ NHTV University of Applied Sciences \\ Academy for Digital Entertainment/Academy for Leisure \\ Archimedesstraat 17, 4816 BA \\ Breda \\ The Netherlands \\ hover.m@nhtv.nl
}

Abstract: Crossroads is the name of the concept that narratively connects several WWII-related cultural institutions in Brabant. It is an overarching paradigm that links together four otherwise very diverse World War II sites, namely, three museums and a commemoration centre.

Crossroads provides these institutions with a tool in the form of a three-layered matrix to build and offer visitors a cohesive experience related to their WWII heritage. This experience is characterised by the specific approach that they can adopt in telling their WWII stories. This approach uses storytelling techniques. This is what the Crossroads matrix is about.

This paper will highlight the creative process that led to the development of this concept and will discuss examples of the resulting non-fiction (transmedia) narratives.

Keywords: digital storytelling, World War II, military heritage, non-fiction (transmedia) narratives 


\section{Introduction}

Although the number of people who directly experienced World War II (WWII) is rapidly declining, the war and the issues connected to it are still relevant today. The international interest for so-called dark tourism sites in general and for those related to WWII in particular is growing. In Brabant, this relevance is mirrored in the great amount of local people visiting WWII-related heritage as well as in the growing international interest for it from countries like Canada and the US which both played a massive role in the liberation of Europe during WWII. ${ }^{1}$ Because of the very diverse nature of the WWII heritage present in Brabant (ranging from a heavy artillery museum to a former concentration camp), more cohesion and collaboration among those institutions is desirable and seems to be needed to offer visitors a meaningful and holistic experience of these sites.

In view of the upcoming commemoration of the $75^{\text {th }}$ anniversary of the liberation of the South of the Netherlands in 2019, a team of experts from NHTV University of Applied Sciences in Breda has been asked by the provincial marketing agency Visit Brabant to investigate how to connect four otherwise very diverse WWII heritage sites (namely, three war museums and a commemoration centre at a former SS-concentration camp) through storytelling. We found a possible connection in the form of a unifying narrative concept that forms the basis for several storylines which can eventually be elaborated in a transmedia way. We called this concept Crossroads.

In order to be connected through Crossroads, museums do not have to share their collection items. Crossroads is, in fact, an overarching paradigm that offers these heritage sites a tool to help them build and provide visitors with a cohesive experience related to their WWII heritage. This experience consists of framing their specific WWII heritage as personal stories according to the three-layered matrix we developed. The storylines that we developed in line with this concept are intended to bring this very specific and still sensitive heritage closer to people, specifically to the museum visitors, by touching them emotionally with a certain type of story told in a specific way. Indeed, not all stories are liable to be told in Crossroads. In order to identify what characteristics a story needs to have to become Crossroadscompliant, we developed a three-layered matrix that encompasses the storytelling perspectives making up this concept.

This paper will present the creative development of Crossroads. It will discuss the three-layered matrix and some of the challenges that come with this kind of collaborated storytelling, and it will also introduce two non-fiction (transmedia) narratives in which this concept is being translated.

\section{The Project Rationale}

As mentioned in the Introduction, the WWII heritage that is present in Brabant is extremely diverse. It is diverse in its content as it comprises, to mention the institutions that were originally involved in this project, the National War Museum Overloon, which covers military heritage spanning over a large period of time and is located close to where a fierce battle between Allied and German troops took place in the fall of 1944; the Camp Vught National Memorial, a previous SSconcentration camp where over 31.000 people from a variety of backgrounds were held as prisoners in 1943 and 1944; the General Maczek Museum in Breda, which is dedicated to the Polish troops who liberated the city from the oppressors; The Wings of Liberation Museum in Best, which originated as a private collection of mainly aircrafts. It is diverse in the experience each site offers, with the Overloon Museum even offering some form of recreative possibilities and Camp Vught providing original videos about life in a concentration camp. Finally, it is diverse in the target group each site addresses, which spans over generations (e.g. in Overloon, with many families visiting the museum to spend an interesting day out due to the recreational offerings), over nationalities (Overloon, again, for the Canadian and American involvement in the liberation of Brabant and the General Maczek Museum attracting mainly descendants of the Polish soldiers who liberated Breda under the lead of Stanislaw Maczek) and over interests (to reconnect with the lost dear ones who fought for the liberation of a foreign country, for Overloon, Mazcek and Best, and to reconnect with their dark past for

1 Adriaan Van Liempt, Jeroen Nawijn, Rami Isaac and Lizzy Klijs, 'Herdenken is 'hot': Over motivaties en emoties van bezoekers aan herinneringscentra' in: NRIT Media-CELTH-NBTC Holland Marketing, Trendrapport toerisme, recreatie en vrije tijd, NRIT Media, $2014,308-310$. 
Camp Vught in particular, which, after the liberation, has been reconverted into a camp for those involved in the NSB people siding with the occupying forces and, ultimately, for prisoners from the Dutch East Indies resistance).

At the moment, each of these institutions tells its own WWII-related stories in a unique way These stories are countless, which is why it was necessary to develop a tool that could help visitors select which stories, among the many more that could potentially be told, best represent the museum in a Crossroads-like way. This tool takes the form of a matrix, which encompasses three storytelling layers: historical, geographical and human (see below). They make a story worth being told in Crossroads. In order to understand the meaning and the value of this matrix, we first need to discuss the creative process that brought about the development of this concept.

\section{The Research Approach}

Practice-oriented research exists at the base of the creative development phase. For this research, we adopted a multifaceted approach that combines secondary research on dark tourism and on World War II in Brabant/the Netherlands with primary research. The latter involves participatory observations of the various locations and interviews with the curators of the four mentioned museums and of various other stakeholders from cultural institutions and provincial organisations.

We will discuss some of these topics (i.e. dark tourism, the meaning of experience and the current use of storytelling in museums and the role of identification), before delving into the process that led to Crossroads stories.

\subsection{Dark Tourism}

Through secondary research, we gained insight into 'dark tourism' - specifically, into the emotions and the motivations of visitors of heritage sites related to WWII.

Reasons to visit memorials and war heritage sites are quite diverse and broad, ranging from personal or emotional ${ }^{2}$ motivations to more practical and concrete motivations. ${ }^{3}$ Next to 'play dice with death' ${ }^{4}$ i.e. to look for locations and experiences that challenge one person's sense of mortality and finiteness, Ashworth ${ }^{5}$ identifies more meaningful motivations for dark tourism that include a desire to go on a pilgrimage, one's search for identity and knowledge and a feeling of social responsibility. Pilgrimage is further explained as the need for memory coupled with educational purposes to not forget the past ${ }^{6}$ and to connect with one's culture and history. ${ }^{7}$ Biran et al ${ }^{8}$ identified four categories of dark tourism motives: i) 'to see it (a war site) to believe' these terrible facts have really happened; ii) 'to learn and to understand'; iii) to visit places where a known person had died/had been killed; iv) to have an emotional experience, i.e. to feel and empathise with the victims and to connect in this way with the heritage. Similarly, Isaac and Cakmak ${ }^{9}$ have identified five reasons why people visit the Memorial Centre Camp Westerbork: self-insight, curiosity, awareness, a must see place and exclusivity. These motives are very similar to those Biran et al. ${ }^{10}$ identified: a recurrent theme is that of gaining self-insight and awareness by experiencing certain places in person.

2 Graham Dann, 'The Dark Side of Tourism', Etuds et Rapports, Série L. Aix-en-Provence, Centre International de Recherches et d'Etudes Touristiques, 1998.

3 Anthony Seaton, 'From Thanatopsis to Thanatourism: Guided By the Dark', International Journal of Heritage Studies, 2(4), 1996, 234-244.

4 Graham Dann, 'The Dark Side of Tourism', 1998.

5 Gregory Ashworth, 'Holocaust tourism: The experience of Kraków-Kazimierz', International Research in Geographical and Environmental Education, 11(4), 2002, 363-367; Gregory Ashworth, 'Tourism and the heritage of atrocity: managing the heritage of South African apartheid for entertainment' in: T.V Singh, ed, New Horizons in Tourism: Strange Experiences and Stranger Practices, 2004, 95-108, CAB International.

6 Ria Ann Dunkley, Nigel Morgan and Sheena Westwood, 'Visiting the trenches: exploring means and motivations in battlefield tourism', Tourism Management, 32(4), 2011, 1-9.

7 Rasul Mowatt and Charles Chancellor, 'Visiting death and life: Dark tourism and slave castles', Annals of Tourism Research, 38(4), 2011, 1410-1434.

8 Avital Biran, Yaniv Poria and Gila Oren, 'Sought experiences at (dark) heritage sites', Annals of Tourism Research, 38(3), 2011, 820-841.

9 Rami Isaac and Erdinç Cakmak, 'Understanding visitor's motivation at sites of death and disaster: the case of former transit camp Westerbork, the Netherlands', Current Issues in Tourism, 17(2), 2014, 164-179.

10 Avital Biran et al, 'Sought experiences at (dark) heritage sites', 2011. 
To conclude, in all the studies mentioned earlier and in many more ${ }^{11}$ recurrent reasons that seem to justify dark tourism include the need to feel connected to a place and to the people who have suffered there. Additionally, through this identification process, it is important to learn from history and to pass this knowledge, insight and awareness on to the younger generations that are, by definition, less connected to these events.

In Nawijn et al.'s study conducted in 2014, 1,050 Dutch visitors older than 18 years were asked about the emotions they felt during their visits to three concentration camps in the Netherlands (i.e. National Monument Camp Vught, Camp Amersfoort and the Memorial Centre Camp Westerbork). Thirty-three emotions were recognised, among which the most prominent were horror, shock, compassion, grief, interest, respect, anger, thankfulness and fascination. ${ }^{12}$

As this study shows, emotions can be positive or negative. In both cases, though, visitors associate these emotions with people: with the victims, in the case of positive emotions, or with the perpetrators, in the case of negative emotions. ${ }^{13}$ Identification is also in this context the key process to be able to empathise (see next). In this study, Nawijn et al. also found that repeat visits to memorial centres are relatively low, but the tendency to recommend a visit to the site to others is relatively high. ${ }^{14}$

\subsection{Museum Experiences}

Most museums are nowadays concerned with the kind of experience they may offer to visitors in order to remain relevant to the people they seek to engage. ${ }^{15}$ War museums and commemoration centres are no exception to this. According to Somers, war memorials in the Netherlands have evolved from being the carrier of a message towards national unity in the 1950s-1970s to actualising this message by making parallels to the contemporary critical political situation in the 1970s-1990s and, after that, to focusing on education. ${ }^{16}$ With the turn of the century - characterised by the rise of the so-called 'experience economy' and an increase in competition between suppliers of leisure activities ${ }^{17}$ war museums have started to focus more on the concept of 'experience'. However, they struggle with what such experiences should look like and how they should differ from what other 'experience' places offer, such as attractions parks.

In this context, Camarero-Izquierdo, Garrido-Samaniego and Silva-Garcia's critical study showed that visitors found the museum visit more pleasant if it involved group activities and the use of technology. ${ }^{18}$ Meaningful and personal connections (e.g. attained through hearing personal stories or through interactions with other visitors) also strengthen the experience. ${ }^{19}$ These studies focus on the emotions visitors felt during the museum visit. This conclusion is reinforced by the results of an earlier study, conducted by Masberg and Silverman, ${ }^{20}$ which shows that students visiting a war museum tend to remember, in addition to the factual information, personal experiences related to what they learned and their co-visitors.

11 Yaniv Poria, Arie Reichel, and Avital Biran, 'Heritage site management: Motivations and expectations', Annals of Tourism Research, 33 (1), 2006a, 162-178; Yaniv Poria, Arie Reichel, and Avital Biran, 'Heritage site perceptions and motivations to visit', Journal of Travel Research, 44 (3), $2006 \mathrm{~b}$, 318-326.

12 Jeroen Nawijn, Rami Isaac, Konstantin Gridnevskiy and Adriaan van Liempt, 'Holocaust Concentration Camp Memorial Sites: An Exploratory Study into Expected Emotional Response', Current Issues in Tourism, 2015, 1-16.

13 Jeroen Nawijn et al, 'Holocaust Concentration Camp Memorial Sites: An Exploratory Study into Expected Emotional Response', 2015.

14 lbid.

15 Nina Simon, The Art of Relevance, 2016.

16 Erik Somers, De oorlog in het museum, Herinnering en verbeelding, WBooks, 2014.

17 Hans Mommaas, De vrijetijdsindustrie in stad en land; een studie naar de markt van belevenissen, Sdu Uitgevers, 2000.

18 Carmen Camarero-Izquierdo, María José Garrido-Samaniego and Rebeca Silva-Garcia, 'Generating Emotions through Cultural Activities in Museums', International Review on Publicand Non-Profit Marketing, 6(2), 2009, 151-165. doi: 10.1007/s12208-009-0032-y

19 Genevieve Alelis, Ania Bobrowicz, and Ang, Chee Siang, 'Exhibiting Emotion: Capturing Visitors' Emotional Responses to Museum Artefacts', in: A. Marcus, ed, Design, User Experience, and Usability'User Experience in Novel Technological Environments, Springer, 2013, 429-438; Nina Simon, The Art of Relevance, 2016, http://artofrelevance.org.

20 Barbara Masberg and Lois Silverman, 'Visitor Experiences at Heritage Sites: A Phenomenological Approach', Journal of Travel Research, 34(4), 1996, 20-25. doi: 10.1177/004728759603400403 
L. Calvi and M. Hover, Crossroads: Life Changing Stories from the Second World War

\section{3 storytelling}

Storytelling is an extensive concept that can be applied to both fiction as well as factual stories.

Telling stories serves to inform others about something, but they are also often told to engage people. ${ }^{21}$ Stories can help people attach meaning to places, images or objects. ${ }^{22}$ Moreover, stories can transmit emotional and symbolic values. And, finally, stories can teach a person something about the world and oneself. ${ }^{23}$

While storytelling is an accepted practice in museums and is a way to better embed the collection on display ${ }^{24}$ our application of it in Crossroads is different: by specifically focusing on the personal story of one or two people (see next), we have ensured that identification was enhanced.

Stories can indeed be powerful as a result of the process of identification. This happens when the readers (or the listeners) can identify themselves with the (struggles and dilemmas of the) main character of the story that is being told. ${ }^{25}$ This process can be further enhanced by the use of images or authentic objects belonging to this main character. In this way, the ultimate experience is then strengthened.

\section{The Creative Development Phase}

\subsection{Crossroads, a narrative concept}

Crossroads (Fig. 1), as a concept, was developed at the end of the research phase. An important finding was that on Brabant soil, all war related historic 'themes' or major 'events', ranging from mobilisation to battles and liberation, had taken place (Fig. 2). This makes Brabant a unique province in the Netherlands, in that Brabant has the potential to tell a complete war narrative, with various locations or sites focusing on a specific theme. Camp Vught, for instance, is the place where the theme of the persecution of the Jews is best expressed. It is a place where life paths crossed and where people arrived and departed, by road or by railway.

Crossroads is a narrative concept in the sense that the word itself resonates stories.

Conceptually, Crossroads indeed indicates the lines that meet and depart at several levels. It is a layered concept that allows several perspectives (Fig. 2):

- From a historical perspective, Crossroads are turning points in the chain of events taking place in the war historic narrative: mobilisation, annexation, occupation, persecution, resistance, battles and, finally, liberation.

- From a geographical perspective, Crossroads represents the routes that physically cross each other and that are still visible in the Brabant landscape, such as roads and railways. It also includes the routes the troops followed when marching through and clashing in Brabant.

- From a human perspective, Crossroads focuses on the personal stories of individual people in Brabant during WWII and on the life changing events that took place. People literally found themselves at a crossroads in their lives.

21 Yiannis Gabriel, Storytelling in Organizations: Facts, Fictions, and Fantasies, OUP Oxford, 2000.

22 Athinodoros Chronis, 'Tourists as story-builders: Narrative construction at a heratige museum', Journal of Travel \& Tourism Marketing, 2012, 444-459.

23 Moniek Hover and Olaf Vugts, 'Efteling en Sprookjesboom. Strorytelling tussen traditie en vernieuwing' in: NRIT, Trendrapport toerisme, recreatie en vrijetijd, NRIT Media, 2013, 272-275; Jack Zipes, Happily Ever After. Fairy Tales, Children and the Culture Industry, Routledge, 1997.

24 Raffaella Trocchianesi, Design e narrazioni per il patrimonio culturale, Maggioli Editore, 2014.

25 Robert McKee, Story. Substance, Structure, Style, and the Principles of Screenwriting, Methuen, 1998. 


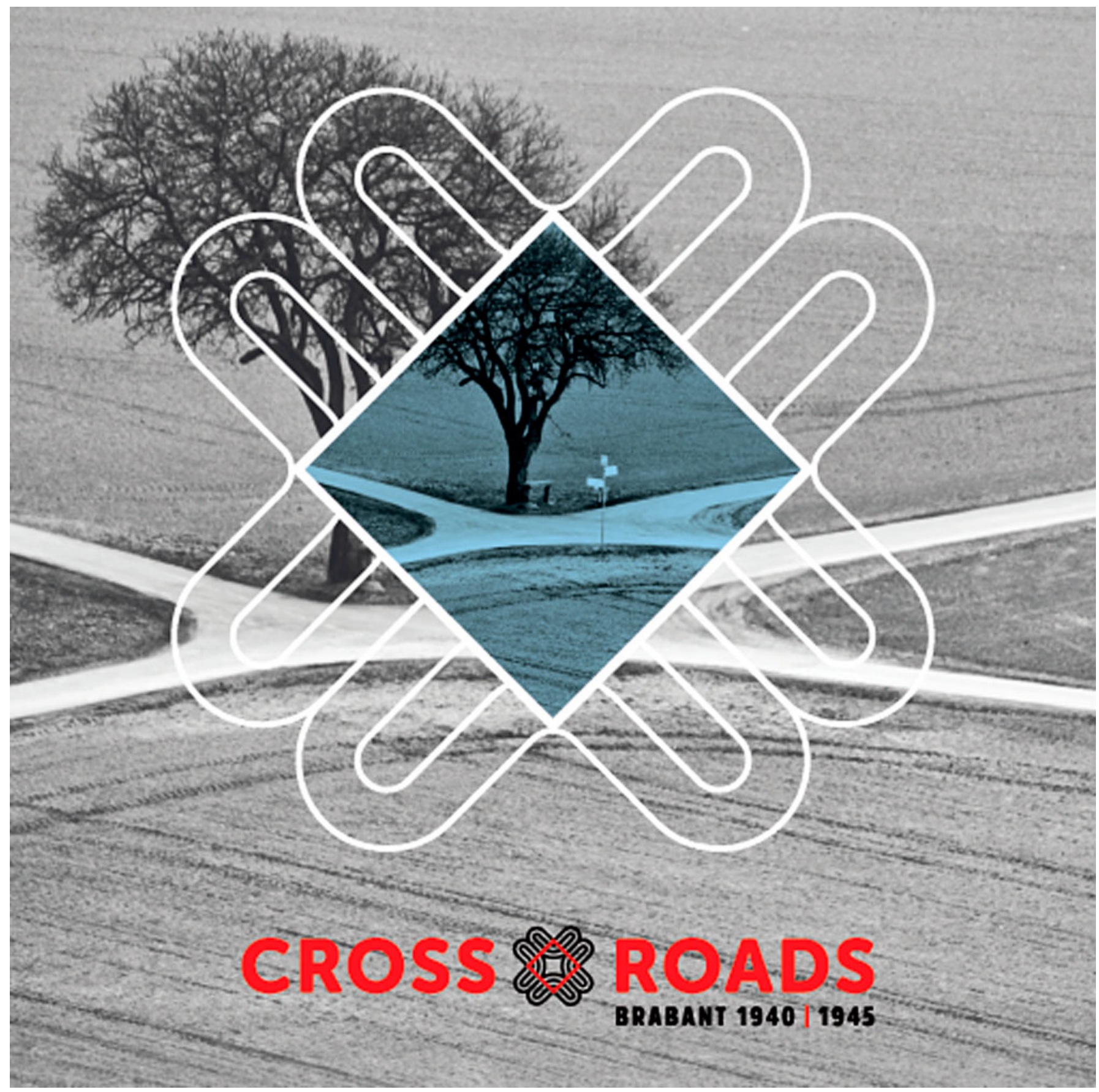

Figure 1. Crossroads.

Additionally, Brabant has the potential to tell many types of stories: personal stories (the who in Fig. 2 below) that are also historically relevant (the when, how and what), in which the context (the why) of authentic locations (the where) can be experienced.

All three layers are important and need to be present to understand any story that is told within Crossroads. Elements from all three layers have to be taken into consideration in order for Brabant to offer a diverse supply of stories at various sites/surrounding landscapes (see Fig. 2). However, we specifically want to focus on the human layer. It is indeed through the human layer that identification with the story's protagonist is possible (see above). Ultimately, this 


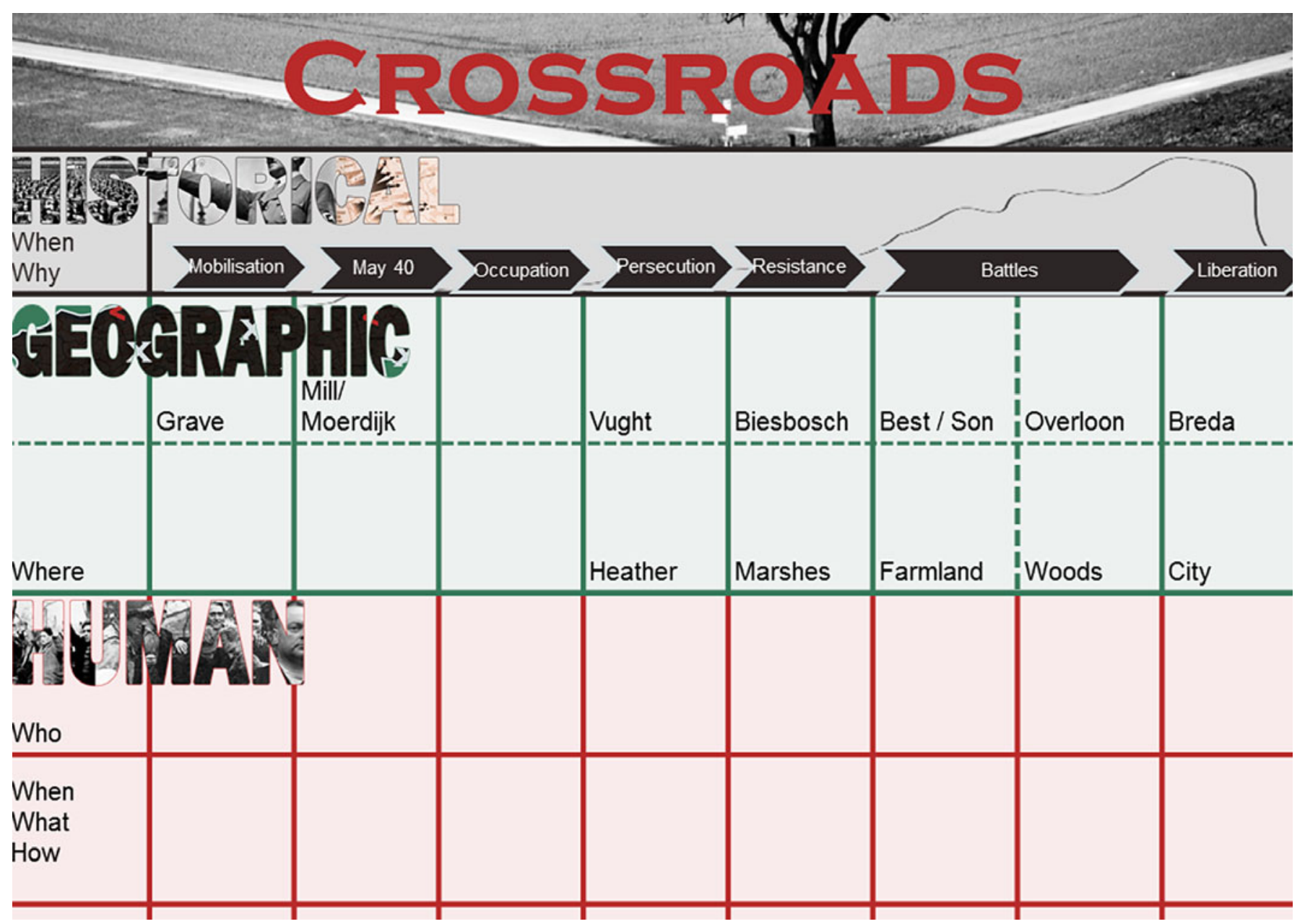

Figure 2. The three storytelling layers in Crossroads.

story can touch visitors emotionally and can give them new insights. The human layer prominently reveals the life changing choices and ordeals people encountered. Moreover, the persons portrayed in these stories and the crossroads they had to face are universally appealing and touch the heart of any visitor, regardless her/his origin or background.

\subsection{Crossroads storytelling}

In everything that is transmitted as a story (orally or in written form, in film or in any other media, factual or fictional, mythological or historical), a basic structure can be recognised. This structure consists of five steps as depicted in

Figure 3 below.

In the Crossroads storytelling approach, however, we have added a prologue before these five steps and an epilogue after them (Fig. 4). The reason for these additions has to do with the fact that we do not intend to tell long and complete life stories in Crossroads. Rather, our focus is on the life changing events that took place during the war in Brabant. The structure of Crossroads stories needs to be simple: easy to tell, easy to remember and easy to pass on to others. In this way, visitors can use the story when recommending a visit to others (see above).

The prologue gives a short overview of the context. Its function in Crossroads is to give a brief historical explanation of the events that took place in the war in the context of the story being told as well as some background information on the protagonist. 


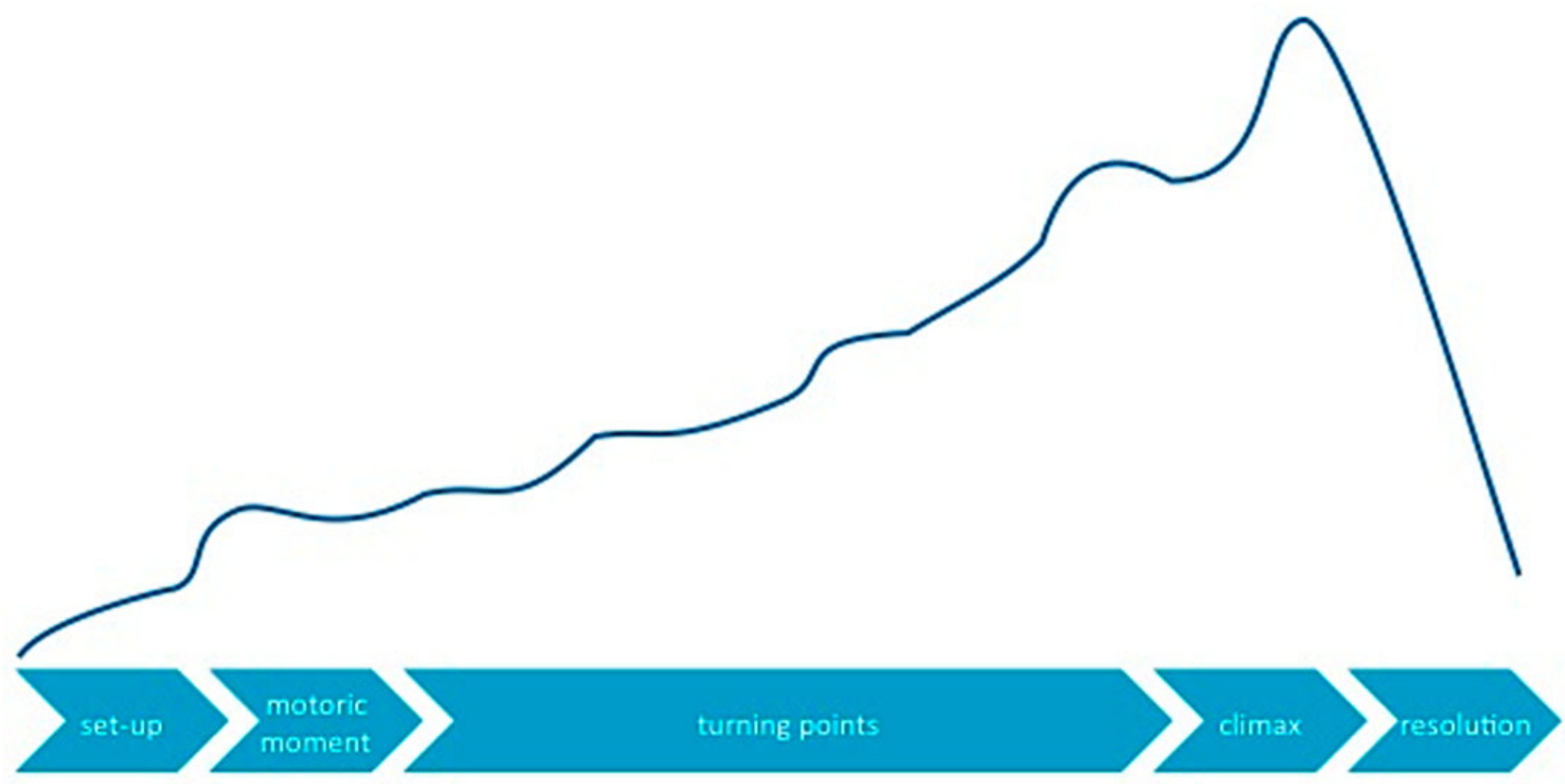

\section{- time and place \\ -introduction of protagonist}

-disbalance?

\begin{abstract}
- event that sets story in motion

-protagonist into action
\end{abstract}

-problem or question: what will happen?

-decisive moments
-heightens stakes
-acceleration

$\begin{array}{ll}\text { •absolute } & \text { •insight } \\ \text { high or low in } & \text { •final } \\ \text { the story } & \text { fecling } \\ \text {-problem } & \\ \text { resolved } & \end{array}$

- question

answered

Figure 3. The five-step model of storytelling ${ }^{26}$

The epilogue details what happened to the protagonist once the events described in the previous steps have been resolved. In Crossroads, the epilogue deals with the impact that the events related to WWII had on the protagonist.

In the creative development phase, co-creative storytelling sessions with several stakeholders took place. In these sessions, we invited each of the involved museums to bring a - more or less - factual story related to its own heritage site and to then retell the story by using the five-step model, complemented by the prologue and the epilogue.

In order to help the participants at the co-creative session further develop their stories, the application of the above mentioned seven-step model was also complemented with a series of questions derived from the principles of screenwriting. ${ }^{27}$ They help the storyteller to better focus on the life changing events as experienced by the protagonist and to better highlight the decisive moments or crossroads that are crucial for story identification. Examples of these questions are as follows: What drives the protagonist? What are the opposing forces? Do these opposing forces test the protagonist as a human being? Do we feel more connected to the protagonist as the story evolves? Can we identify with the protagonist?

26 Moniek Hover, De Efteling als 'Verteller' van Sprookjes, Efteling Publishing, 2013; Andrea Philips, A Creator's Guide to Transmedia Storytelling, McGraw Hill, 2012; Brian McDonald, Invisible Ink. A pratical guide to building stories that resonate, Libertary, 2010; Marie-Louise Von Franz, The Interpretation of Fairy Tales, Shambala, 1996.

27 Robert McKee, Story, Substance, Structure, Style, and the Principles of Screenwriting, Methuen, 1998. 


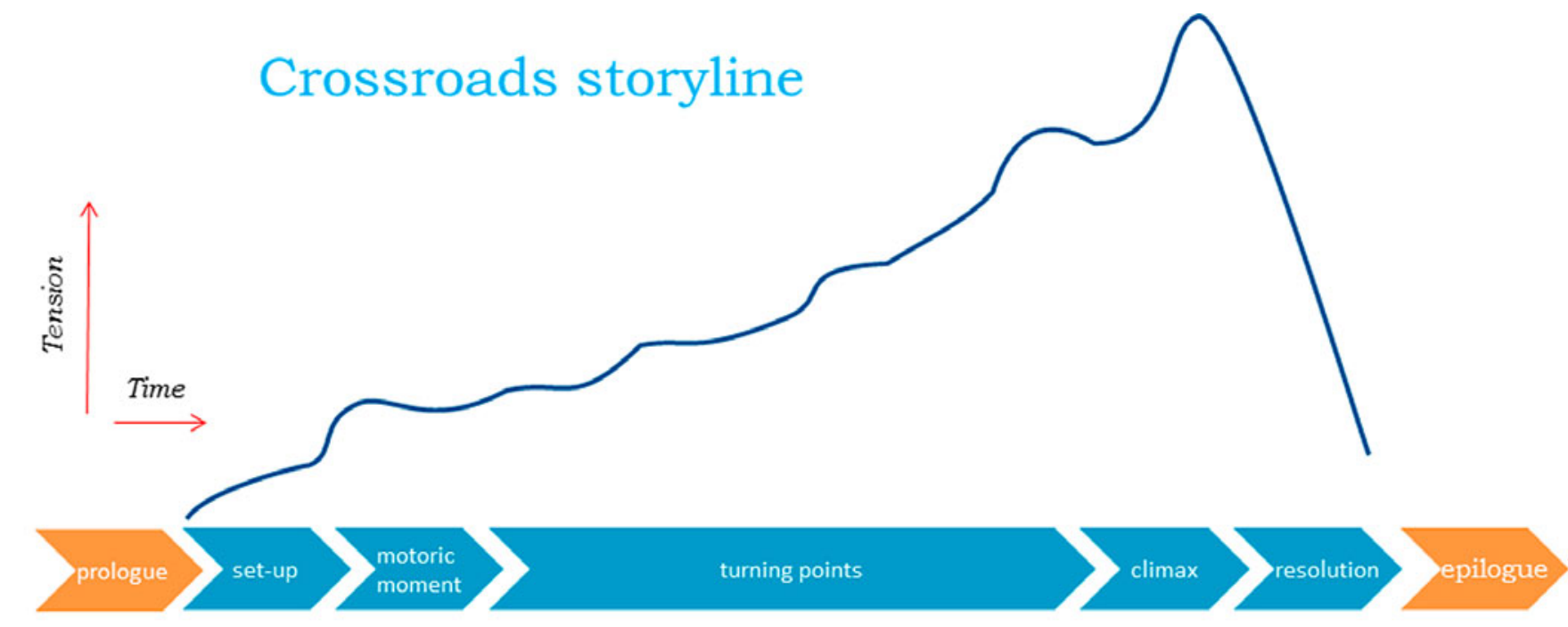

-short

historical

background

-short

background of

protagonist

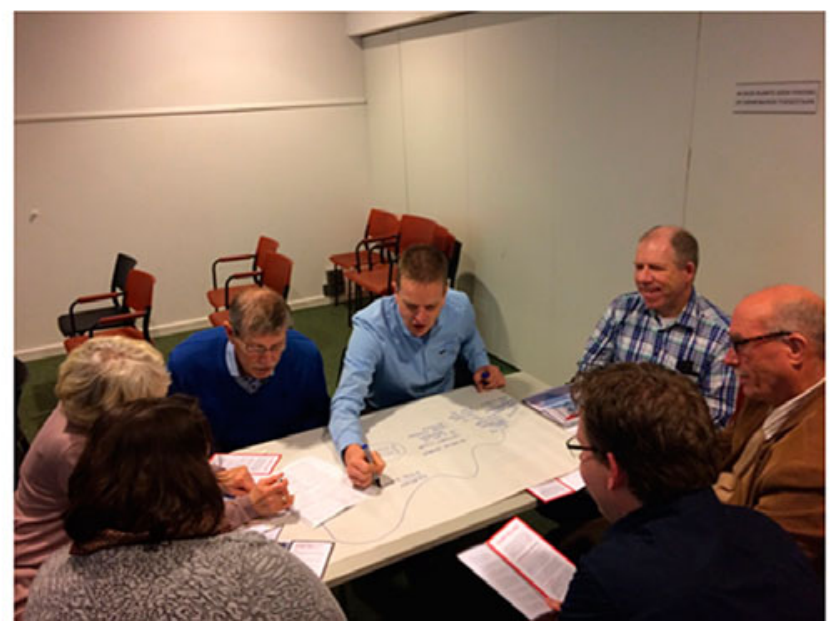

- how it all ended for protagonist: after life

-impact of WWII on his/her life

Figure 4. The seven-step Crossroads model of storytelling applied in a co-creative session. ${ }^{28}$

\section{The Crossroads Stories Brought to Life in Museums}

In the follow-up phase of the project, Crossroads was turned into a banner exhibition, which is currently on display at four locations in the province (Fig. 5).

This fairly traditional way of storytelling consists of pictures and written texts for visitors to see and read. The next phase will explore how digital/transmedia storytelling can be applied.

A first step in this process involved a research project by Linsey van lersel, a Leisure Management student at NHTV Academy for Leisure (2016). Linsey created an interactive, digital presentation of the story of George and Ursula Levy (Fig. 6 , see below), which she then tested with several focus groups consisting of families with children aged 9-15 years old.

\subsection{George and Ursula Levy}

The story of George and Ursula Levy (Fig. 7) is related to Camp Vught and to the children's transport that departed from there: 1,269 children were deported with false pretexts from Camp Vught in 1943 and were ultimately gassed. George and Ursula survived this ordeal. 


\section{VIEU}

L. Calvi and M. Hover, Crossroads: Life Changing Stories from the Second World War

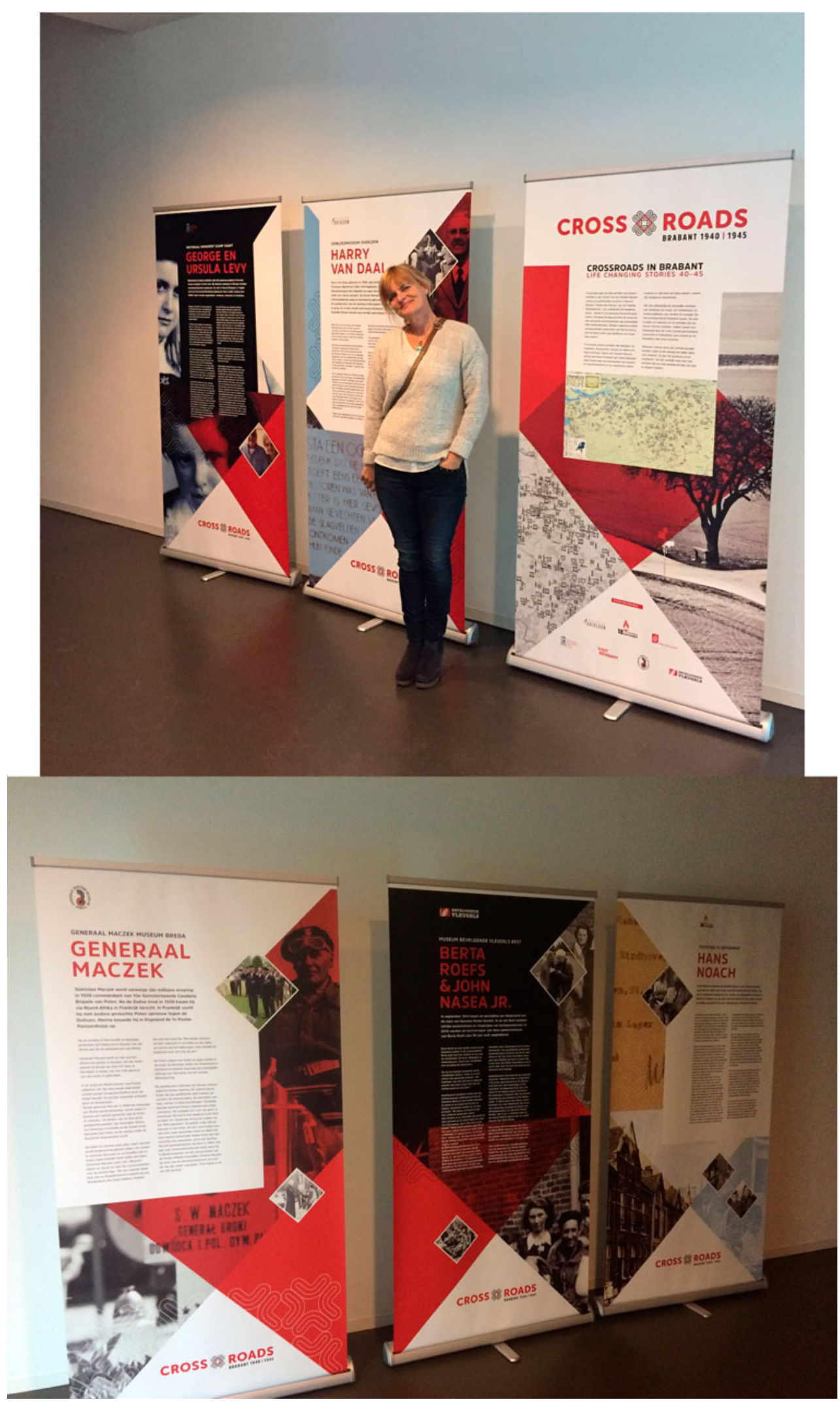

Figure 5. Banner Exhibition Crossroads at Camp Vught (opened 21 November 2016) 


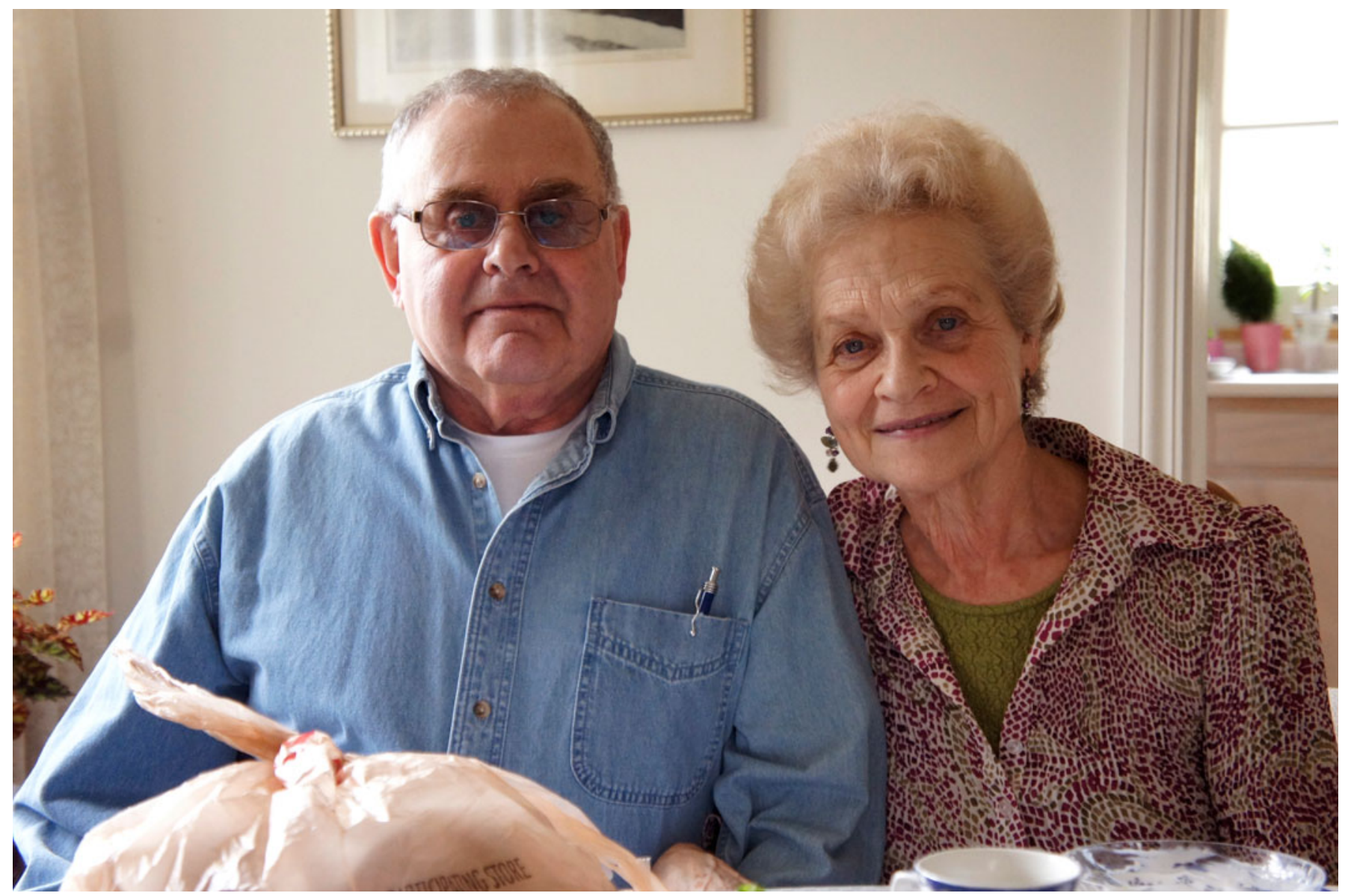

Figure 6. George and Ursula Levy in the NTR documentary Andere Tijden

What follows is a summary of their story, inclusive of a clear identification of the seven steps from the storytelling model depicted in Fig. 4.

\subsection{Prologue}

George and Ursula Levy were born in Germany. The Nazis caught their father during the Night of the Broken Glass. He died shortly after, leaving his wife with their two young children.

\subsection{Set-up}

In 1939, George and Ursula, then 9 and 4 years old, were sent to the Netherlands. Their Jewish mother had instigated this move with the hope that they would be safe in this country. Thanks to the help of Jozef van Mackelenbergh from Den Bosch, nuns from the convent in Eersel rescued the children.

\section{4 Motoric moment}

However, the nuns could not prevent the children's eventual departure to Camp Vught in April 1943. Since the children had no parents, another camp prisoner, Florence, was appointed to be their carer. Life in the camp was extremely difficult, especially for young children: there was hardly anything to eat, and many children became sick. Yet, George attempted to look after his younger sister as much as possible. While they were in the camp, Jozef van Mackelenbergh visited them regularly. 


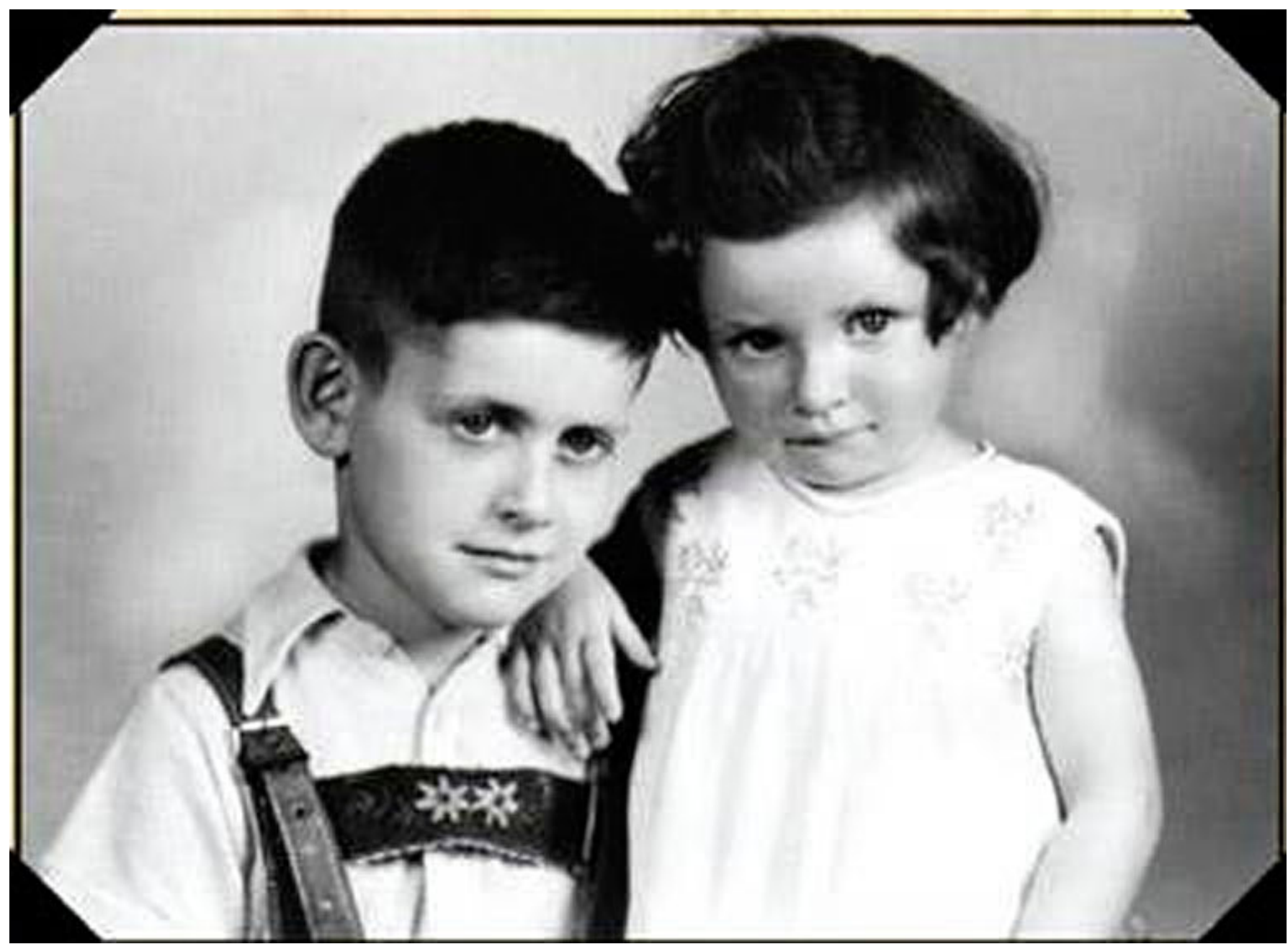

Figure 7. George and Ursula Levy.

\subsection{Turning point}

In June 1943, the Nazis decided that all Jewish children under the age of 16 years had to be deported from the camp. In reality, the children were transported to an extermination camp that passed through Westerbork. Jozef van Mackelenbergh succeeded in convincing the camp commander that George and Ursula had a Catholic father in the United States. As a result, he kept them from being put on the children's transport that eventually led to the death of 1,269 Jewish children. However, George and Ursula were not entirely out of danger.

\subsection{CI im ax}

At some point, another transport was announced, and Florence was to be put on it. Florence started shouting that she had to be with the Levy children because they needed her. Then, an SS-guard turned to George and asked him if they really needed her. If he had said 'yes', there was a slim chance that Florence might have stayed with them and escaped death. But there was also a much greater chance that both he and Ursula would be put on the same transport with Florence and exterminated. If he had said 'no', however, Florence would certainly be deported, but then the children might have been safe, at least for the time being. So, 'No', he said, 'We don't need her'.

\subsection{Resolution}

As a 13-year old boy, George had to make a terrible decision about life and death, for others and for himself. 'It bothered me very very much for many many years. I used to have nightmares over that', he testified many years later. 


\section{De pop van Ursula}

Dan is het zover, op 6 juni vertrekken de kinderen van 0 tot 3 jaar met hun moeder op transport. De volgende dag vertrekken de oudere kinderen van 4 tot 16 jaar met hun vader of moeder.

In het volgende fragment vertelt Ursula over deze dag. Er wordt haar gevraagd of ze haar pop wil afgeven aan een kindje wat mee moet op transport.

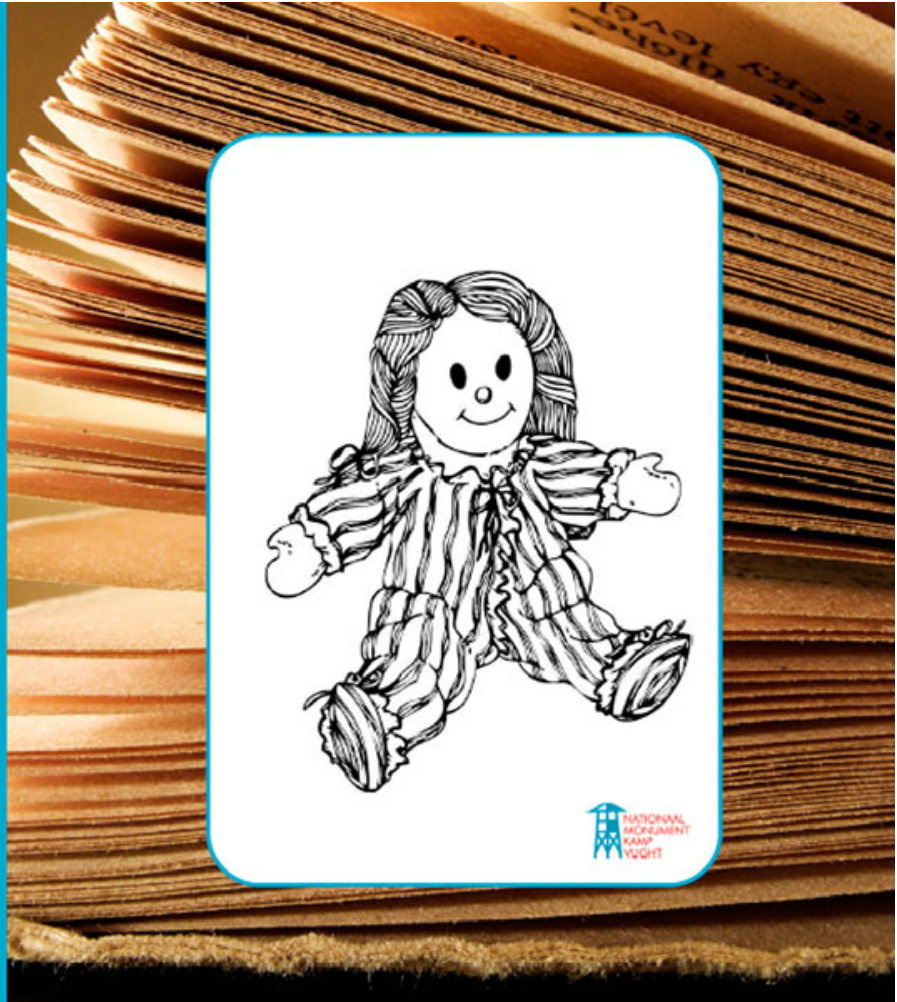

Figure 8. The fragment about Ursula's doll.

\subsection{Epilogue}

Eventually, George and Ursula were also deported to Bergen Bergen, via Westerbork. However, they both miraculously survived the war. After a rough journey, they knocked at the Van Mackelenbergs' door in Den Bosch in 1945. They were welcomed with open arms. They were able to go back to school in the convent in Eersel where they have lived until finally emigrating to the United States in 1947, where their aunt and uncle raised them, their mother not having survived the war. They are both still alive and have written and talked about the terrible events they experienced. They are still grateful for the short period of time they had spent with their loving parents. As Ursula Levy states in her online testimony as a Holocaust survivor, 'We had wonderful parents. I had four years of their nurturing, love and caring. I believe that those early beginnings helped us through the rest of our lives'.

Additionally, several books, pictures and videos about this story exist. Linsey's digital, interactive presentation was composed of pictures of George and Ursula, drawings and video fragments from documentaries about the children's transport, such as fragments from the documentary in which George and Ursula share their story in a filmed interview, which was broadcast on Dutch national television on 4 May 2016. In the presentation, Linsey followed the Crossroads storytelling model with the prologue, the five steps and an epilogue. She added a turning point that might be of special interest to children. In the documentary, Ursula explains that shortly before the children's transport, a fellow prisoner asked her to give her only doll to one of the other children (Fig. 8). Ursula could not bring herself to do this because it was the only thing she had.

During the focus group, Linsey showed pictures and video fragments and invited the parents to read aloud the text that accompanied a certain step to their children (thus combining oral storytelling with digital storytelling). After each step, she provided a question for the family members to answer and to discuss. For example, after the fragment about the two children being sent to the Netherlands and becoming separated from their mother, the children were asked whether they had ever been separated from their parents for a longer period of time and, if so, how they had felt. This same paradigm was used for other salient episodes in George and Ursula's life, like George trying to take care of Ursula under very difficult circumstances. 
The purpose of Linsey's study (van lersel, 2016) was to verify what children aged 9-15 and their parents experienced when participating in this interactive presentation about George and Ursula. Another aim was to determine the extent to which they could draw connections between what they had heard and seen and their own lives.

What emerges from her study is that both groups of participants can understand this Crossroads-based story, although sometimes they would need some additional information. The children indicated that their understanding of Ursula's decision to not give away her doll, for example, depends on whether or not Ursula knew at the time that the children would eventually be killed. The children can instead very much relate to the brother taking care of his little sister. As such, they do understand George's decision to say that he does not need Florence. The notion of becoming separated from their parents and never seeing them again, however, is beyond their comprehension.

This story affected children as well as parents, and they expressed a willingness to pass it on to others when the right opportunity arose. The story has led to conversations between parents and children and has stimulated the children to take care of others, such as when visiting or helping their grandmothers.

Moreover, these results indicate that a Crossroads-built story expressed in an interactive manner, using a variety of media, has (more) potential to touch visitors.

\section{The Oberlangen Women: an AR Experience}

A story that we are currently preparing is the story of the Oberlangen women, which is related to the General Maczek Museum in Breda. This story, like the previous one, is following the Crossroads model in terms of its structure and the way in which it is built.

This story will be rendered into a mixed reality experience, combining physical elements among those displayed in the museum and digital elements from their own archive into an augmented reality (AR) app to augment it and bring it to life. Through the AR layer, the objects also develop, next to their actual properties, a personal and emotional load.

Augmented reality (AR) adds a virtual layer on reality that makes the real-time augmentation of physical objects possible. In this way, these augmented objects become interactive and digitally manipulable. So, it is possible for the viewer to access additional information or background stories about the environment or about the collection items themselves because the virtual layer is based on a real physical experience (as many examples, also of AR-supported gallery explorations from the British Museum testify). AR allows visitors to experience stories by watching or listening to them digitally. But what is most particular is that visitors can decide from which perspective they want to experience the story: in this example, they can choose either from the perspective of a female prisoner or from that of a liberating soldier, or even from the perspective of a German warder. This intensifies the identification process and consequently the experience itself.

Therefore, the choice of AR does not replace the real visit to the museum with a digital experience. On the contrary, it strengthens it as it combines real objects, digitised audio-visual material from the museums' archives and newly built digital elements.

\section{Conclusion}

In this paper, we have presented the development of a narrative concept, Crossroads, which we have used to connect highly diverse institutions in Brabant, all dealing with WWII heritage. This concept, and the model it implies, provides a tool through which their WWII heritage can be rendered in the form of stories and the resulting experiences (for visitors) can be unified across heritage sites. 
The two example stories we have presented in this paper are inherently transmedia because they rely on more means to be told: either orally, via a real storyteller like those normally present at these institutions, or by means of a digital medium requiring a more direct and active involvement from the audience. These are non-fiction (transmedia) narratives, because they only use factual information but in a non-conventional way that can transform the audience (through the insight gained by the identification process central to storytelling) and their environment (e.g. via AR). Notably, van lersel's (2016) study highlights how these narratives are received by the audience and the types of audience engagement they engender: the audience can easily identify with the protagonists and are deeply touched by their stories.

Another kind of engagement refers to the institutions involved and the way they have responded to these possibilities and developments, with the challenges we were faced with during this project, especially when dealing with storytelling and visitor experience on the one hand, and the delicate material of true, personal stories on the other hand. Their challenges were not less, though. They had to open up their archives on very sensitive material to us. Moreover, they had to overcome certain prejudices about rendering such delicate subjects through media, like AR for example, which are too often only associated with games and entertainment.

\section{Acknowledgments}

We would first like to thank our colleagues who participated in this project: Juriaan van Waalwijk, Frank Ouwens, Vincent Neveu and Caroline Segers-Pennings, and the colleagues from the Academy for Tourism for their study on dark tourism that was included in the original project report: Jeroen Nawijn, Adriaan van Liempt and Rami Isaac. Next, we would like to thank the four institutions involved that shared their time and knowledge with us, as well as Visit Brabant, Erfgoed Brabant and the Brabant Province for subsidising this project. Additionally, we want to thank our students from both the Leisure and Digital Entertainment Academies, particularly Linsey van lersel for transforming the stories developed during this project into transmedia narratives.

\section{Bi o graphy}

Dr Licia Calvi is a Senior Lecturer and Researcher at the Academy for Digital Entertainment and the Academy for Leisure, at NHTV University of Applied Sciences in Breda (the Netherlands), where she teaches courses in Interactivity and in Media Theory. Her research is about museum experience design and the use of digital storytelling for cultural heritage. She has been experimenting with various technologies (VR and AR, mixed media) and applied the notion of performance to inform the design of interactions in public and semi-public settings, like museums. Projects she has worked on include the van Gogh Brabant project and Van Gogh Oculus Rift project for the Van Gogh celebration in 2015, and the World War II heritage sites project. In 2016, she co-organised a design research workshop on Museum Experience Design at $\mathrm{CHI}$ 2016, the leading conference in Human-Computer Interaction. The results of this workshop will appear in 2017 as a curated book that she will co-edit for the Springer series in Cultural Computing.

Dr Moniek Hover is a Professor of Storytelling at NHTV University of Applied Sciences in Breda (the Netherlands), where she teaches in the applied and the academic bachelor's and master's programmes in the field of leisure and tourism. Since 2009, together with the Creative Director of the Efteling, she leads the Efteling Academy, an in-company, multidisciplinary talent development programme for students in the field of storytelling, brand development, creative production and performance. At NHTV, she leads the research programme li ne of storytelling and consumer experience. With multidisciplinary NHTV teams, she provides (storytelling-based) research and development projects in the field of leisure and tourism (such as experiences/events related to the international Van Gogh year in 2015, to the commemoration of the 500th anniversary of the painter Jheronimus Bosch's death in 2016 and to World War II heritage sites).

VIEW Journal of European Television History and Culture Vol. 5, 10, 2016 DOI: 10.18146/2213-0969.2016.jethc112 Publisher: Netherlands Institute for Sound and Vision in collaboration with Utrecht University, University of Luxembourg and Royal Holloway University of London. Copyright: The text of this article has been published under a Creative Commons Attribution-Noncommercial-No Derivative Works 3.0 Netherlands License. This license does not apply to the media referenced in the article, which is subject to the individual rights owner's terms. 